Article

\title{
The Sustainability of Global Chain Governance: Network Structures and Local Supplier Upgrading in Thailand
}

\author{
Sungchul Cho ${ }^{1}$ and Up Lim ${ }^{2, *}$ \\ 1 Korea Environment Institute, 370 Sicheong-daero, Sejong 30147, Korea; sccho@kei.re.kr \\ 2 Department of Urban Planning and Engineering, Yonsei University, 50 Yonsei-ro, Seodamun-gu, \\ Seoul 03722, Korea \\ * Correspondence: uplim@yonsei.ac.kr; Tel.: +82-2-2123-5897 \\ Academic Editor: Tin-Chih Toly Chen \\ Received: 29 July 2016; Accepted: 5 September 2016; Published: 8 September 2016
}

\begin{abstract}
Although it has been widely accepted that insertion into global production networks may play a critical role in fostering local supplier upgrading, scholars have yet to fully incorporate heterogeneous configurations of buyer-supplier relationships within networks into empirical testing. Using a representative sample of manufacturing firms in Thailand, we propose a more nuanced empirical framework that asks which features of buyer-supplier relationships are related to which aspects of local supplier upgrading. Our findings, derived from latent class analysis, show that the ways value chains are governed can exert varying effects on different types of technological upgrading. Being a multinational corporation (MNC) supplier was found to have positive effects on process and minor product upgrading, irrespective of the types of buyer-supplier networks. However, we found a more radical type of upgrading (i.e., the development of own brands) to be negatively related to insertion into 'quasi-hierarchical' or 'buyer-driven relationships', whilst involvement in 'cooperative networks' was associated with a significantly higher tendency of product and brand upgrading. Understanding this inherent relationality provides a crucial balance to previous firm-level findings, suggesting that the sustainability of participation in global value chains depends on the relational structures in which local manufacturers are embedded.
\end{abstract}

Keywords: global production network; technological upgrading; network structure; sustainable industrial development; latent class analysis

\section{Introduction}

Nothing defines the nature of globalization in the productive sphere more than a high degree of functional integration on a global scale. As a consequence, the sustainability of industrial strategies pursued by developing countries has increasingly relied on tangible and intangible resources flowing from a whole variety of interactions within global production networks (GPNs). Yet, perhaps surprisingly, there is a lack of consensus in the literature about whether the globalization of production is conducive to local supplier upgrading. Some argue that linkages with global lead firms essentially create new opportunities for technological upgrading on the part of indigenous manufacturers [1]. Still, others emphasize the distorting effects of GPNs on local capability building, such as a lock-in situation that prevents low-tier suppliers from moving to higher stages of production $[2,3]$.

Such conflicting views may represent varied progress of technological upgrading among participating suppliers, with many of them still lagging behind despite a decades-long involvement in global value chains. A more nuanced view on this issue, therefore, suggests that it is not a firm's involvement in GPNs per se but the relational architectures wherein firms are embedded that shape the prospect of supplier upgrading in a host country [4]. In light of this, insertion in a GPN should 
not be conceived a priori as beneficial or harmful to the long-term competitiveness of supplier firms in a universal fashion. Instead, whether connections with global firms translates into local capability formation is inherently a relational process where the practice of asymmetric power relations determines the extent to which suppliers can gain access to international knowledge flows [5].

Capturing this inherent relationality and its structural outcomes is essential for ensuring sustainable development of emerging economies in this era of globalization. It is thus unfortunate that, although much has been written on the role of global lead firms in fostering international knowledge diffusion, only a few studies have, until recently, explicitly examined how different network modes exert asymmetric impacts on the learning opportunities of local suppliers. Answering this question obviously requires an appropriate research design that makes explicit the causal links between network architectures and technological upgrading. Yet in the absence of available data in developing countries, studies deriving causal explanations from firm-level observations are relatively rare, and are based mostly on a small number of firms [6,7].

The purpose of this study is to examine whether, and under what conditions, insertion into GPNs impact the process of local supplier upgrading. More specifically, we aim to extend previous sector-level studies by providing a micro-level framework through which the relative gains and losses from insertion into GPNs can be assessed. Drawing from nationally representative firm-level data in Thailand, this article examines which modes of value chain governance are associated with which aspects of technological upgrading on the part of suppliers. Utilizing a statistical technique of latent class analysis, we identify the unobserved clusters of relationships in which suppliers interact with their global buyers. In turn, we conduct a set of logit regressions suggesting that insertion into a 'quasi-hierarchical' or 'buyer-driven manufacturing' governance contributes to the facilitation of less radical types of product and process upgrading, but also discourages suppliers from moving to higher functions in a value chain. On the contrary, this study demonstrates that firms that are in a 'cooperative network' cluster show a higher tendency to achieve all types of technological upgrading compared to the firms that do not interact with MNCs.

This paper is structured as follows. The next section discusses the previous literature and the theoretical rationale behind our empirical investigation. Subsequently, the context of manufacturing sectors in Thailand is briefly introduced, followed by a discussion of the features of datasets, variables, and empirical strategies. Next, we present and interpret the empirical findings derived from a latent class analysis and logit regressions. This paper concludes by discussing the implications of these findings for studies of technological change in developing countries, as well as for the GPN literature.

\section{Literature Review}

Two long-established strands of research suggest that the process of technological change considerably differs between developed and developing countries [8,9]. On the one hand, scholars of catching-up focus on the internal learning mechanisms employed by latecomer firms, discussing the developmental states' roles in fostering such firm-level efforts $[10,11]$. On the other hand, the GPN scholars depict the process of international knowledge transfer, which is grounded on a particular structure of globally dispersed networks [12]. However, all of these studies highlight the strategic intent of developing country firms as a key factor driving technological upgrading in its own right.

First, the catching-up literature shows that the distinction between innovation and diffusion is often blurred in the context of developing countries due to the importance of incremental innovations that take place during the phase of diffusion [13]. The "old" neoclassical economic literature tends to view innovation as something that occurs at the technological frontier, while conceiving of diffusion as a passive adoption of machineries that embodies ready-made technology [14]. However, diffusion is not an automated process but requires conscious innovative activities to make effective use of existing technologies. Such learning efforts involve incremental improvement in product design and quality, continuous modifications to the ways products are made, and technological strategies to adapt production to local circumstances, all of which should be considered an intrinsic part of a broader sense 
of innovation. In this sense, Kim [15], drawing from an analysis of Korean electronics firms, illustrates the so-called imitation-to-innovation sequence, wherein developing country firms gradually develop their innovative capabilities through imitating first-world technologies. In light of this argument, it seems clear that adopting a narrow definition that equates innovation with breakthrough inventions can be quite misleading by overlooking the contribution of a learning-by-imitation process to the innovative competitiveness of developing countries.

Second, the GPN literature shows that technological upgrading in a developing country is to a large extent driven by strategic coupling with MNCs. Contrary to the Western high-tech regions such as Silicon Valley in California, latecomer economies typically lack endogenous assets that facilitate the nurturing of innovative capabilities, for example, favorable institutional set-up, entrepreneurial business cultures, or highly-educated labor forces [16]. In the absence of such self-contained regional assets, local capability formation is significantly connected to the extent of knowledge diffusion transferred via extra-local interfirm networks. At the same time, there is a growing need for MNCs to adapt production in conjunction with specific local conditions due to: (a) the increasing technical complexities of production; (b) the rapid pace of technical change in the industry (c) and the host countries' incentives that requires global firms' contribution to local capability formation $[17,18]$. For these reasons, MNCs have been increasingly spurred to engage in knowledge transfer or even joint $R \& D$ along the value chains, such that local suppliers are provided opportunities to get access to international knowledge flows. Of course, the ways that international $R \& D$ is coordinated are not all the same. Recent studies, drawing from a perspective of risk management, reconsiders the emergence of different forms of chain governance as reflecting the global lead firms' perceived risk of production disruptions [19-21]. This literature suggests that MNCs may organize different types of supply chain networks as a risk-sharing strategy that helps them to cope with the downstream risks arising from suppliers' performance failures [22]. Where the odds of supplier failure in processes of orders and production are thought to be high, it is likely that global lead firms organize their supply chain networks in hierarchical ways. On the contrary, global buyers are more likely to cooperate with suppliers in a more reciprocal, interdependent relationship when the perceived risk is thought to be low [23].

Combining these streams of research, there has been a limited, but suggestive body of studies that provide plausible explanations for how the opportunities of supplier upgrading are conditioned by the relational structures in which local producers interact with global buyers [24]. Most prominently, Ernst and Kim [25] pioneered the idea of theorizing local supplier upgrading in relation to the strategic coupling with the requirements of GPNs. They argue that the process of knowledge diffusion in a GPN is spurred by concerted efforts of network flagships and local suppliers, which involves various knowledge conversion activities required for suppliers to internalize transferred knowledge into their own capabilities. During this process, global lead firms often invite engineers working for supplying firms to their training program or even send their own technicians to local production facilities to solve on-site problems. Simultaneously, local suppliers strive to exploit as much of the knowledge transfers from MNCs as possible via internal R\&D efforts, training programs, and the development of external knowledge links with various local actors (e.g., local competitors, universities, governments, associational organizations).

However, local capability formation through GPNs often comes at a cost. Humphrey and Schmitz [26] suggest that the process whereby local manufacturers learn from connections with global buyers should be conceived as a political process wherein actors bargain over the terms on which production is organized. This bargaining process, which is sometimes called "strategic coupling" [27], typically generates an unequal distribution of power, which, in turn, limits the learning opportunities of local suppliers. Where global buyers strictly specify the characteristics of products to be produced, suppliers' products are more likely to be delivered solely for the customer's needs. Plausibly, this situation can limit the local supplier's autonomy in production-related decisions. The authors further observed that insertion in quasi-hierarchical relationships with global lead firms, characterized by the asymmetry of power in favor of global lead firms, may lock participating suppliers into low-value 
adding activities (i.e., assembling imported parts). This quasi-hierarchical type of value chain governance may limit the opportunities for local suppliers to develop their own design, marketing, and branding capabilities. These are essential competencies for handling the entire working process for supplier firms themselves, but also could be seen as an invasion of a global lead firm's territory.

Based on the above discussion, it seems reasonable to assume that variation in buyer-supplier network structures is systematically related to different learning opportunities for supplier upgrading within production networks. We thus hypothesize that the effect of insertion in GPNs on participating suppliers' technological upgrading is contingent upon the modes of buyer-supplier relationships as well as the types of technological upgrading. The more hierarchical the types of buyer-supplier networks, the smaller the opportunities for radical types of technological upgrading, such as the development of new product lines or brands that allow suppliers to acquire new functions in a value chain. On the contrary, more incremental types of technological upgrading-e.g., modifications to production processes-would basically depend on the intensity of knowledge transfers in networks wherein the suppliers are embedded, regardless of whether the type of networks is hierarchical or cooperative. In the following sections, the hypotheses above will be operationalized and put to the empirical test on the basis of firm-level data in Thailand's manufacturing sectors.

\section{Methods}

\subsection{Study Context}

The case of the manufacturing sector in Thailand stands out as an interesting setting for asking questions about how local supplier upgrading relates to the network structures wherein indigenous manufacturers interact with global lead firms. Over the past few decades, the stages of industrialization in Thailand have been driven by a massive amount of foreign direct investment (FDI). At its initial stage, MNCs focused on producing labor-intensive consumer goods in an attempt to exploit labor cost advantages as well as a large domestic demand in Thailand. Yet since the mid-1970s, MNCs began to invest heavily in export-oriented products that can be sold in world markets, which, in turn, induces backward linkages with local downstream producers. As a consequence, Thailand has become one of the largest production sites of the electronics and automobile industries [28]. In 2013, the annual amount of FDI accounts for approximately 4 percent of Thailand's GDP [29].

Of course, a large share of inward FDI in GDP does not necessarily guarantee its contribution to local capability formation. Although the importance of export-oriented manufacturing as a driver of Thailand's growth has been acknowledged, the evidence linking insertion into GPNs to local upgrading opportunities is mixed. On one hand, the Thailand MNC suppliers have appeared to obtain processing capabilities through apprenticing with, or direct transfer from, global buyers [30]. However, findings also show that international knowledge transfer has been confined to process technology and minor product design adaptations, and that suppliers working for global buyers have generally failed to move to a more active role of selling complete products with their own brands. Consequently, despite significant progress in the productive sphere, a majority of local suppliers still lack the design and marketing skills needed to acquire higher functions within value chains [31]. This, in turn, raises a critical question that will be addressed in this article-why have a large portion of MNC suppliers in Thailand, but not all, failed to break out of the technological lock-in situation in a value chain?

\subsection{Data}

Our analysis is based on firm-level data from the Productivity and Investment Climate Survey (PICS), conducted by the World Bank and the Thailand Government. The PICS provides two important analytical advantages. First, following the Oslo Manual [32], its questionnaire addresses a broad range of innovative activities, ranging from introducing minor process improvements to developing major new product lines. Second, unlike most innovation surveys-e.g., the Community Innovation Survey by Eurostat - which sample on the dependent variable and thus omit non-innovating firms, the PICS collects a nationally representative sample of registered industrial firms, no matter whether 
or not they report innovative outcomes. Finally, the PICS includes detailed information on the nature of relationships between global retailer firms and local supplier firms. Taken as a whole, this rare representative sample of Thailand manufacturers is uniquely suited to the analysis of local supplier upgrading in the context of GPNs. To increase the number of cases, we pooled the two waves of PICS samples collected in 2004 and 2007. These two datasets are compatible to each other in that they were collected with the same questionnaire and sampling techniques. Service industry firms were excluded as we wished to focus on local manufacturers working for global lead firms. The final full sample for all analyses, as a consequence, was 2128 .

\subsection{Variables}

Taking a global view, Hobday [33] describes technological upgrading in East Asian firms as a process of acquiring more sophisticated, higher income activities within value chains, moving from original equipment manufacturer (OEM) to original design manufacturer (ODM) and original brand manufacturer (OBM). Consistent with this perspective, Humphrey and Schmitz [7] identify three types of technological upgrading considered in the literature-process, product, and brand upgrading. OEM suppliers are required to achieve continuous improvement in both product design and process technology, which allow them to meet global buyers' demanding standards cost-effectively. However, moving into higher value-added functions requires firms to develop their own product lines and brands. To capture these stages, we employ a set of PICS survey items representing whether a firm introduced a new technology that has substantially changed the way the main product is produced (Process), upgraded an existing product line (Minor Product), or developed a major new product line (Major Product) in the last two years. In addition, we include a measure of brand upgrading that specifies whether a firm has its own brand (Brand).

Four measures are employed to capture the heterogeneity of network structures formed by global buyers and local suppliers. The former two measures refer to the extent to which supplier firms are committed to R\&D collaboration with MNCs. Respondents were asked ( $0=$ no or $1=$ yes) whether their buyers (a) engage them in process or product R\&D type of activities (MNC RED); or (b) send employees to disseminate and diffuse new technologies into supplier firms' production facility (Send). On the other hand, the latter two describe the ways through which MNCs control supplier firms to ensure that products meet the required quality standards; Respondents indicated (c) the percentage of sales made exclusively to suit their buyers' specifications (Specification); and (d) whether their buyers enforce certain product quality standards to be attained (Standards; $0=$ no or $1=$ yes).

To correct for potentially confounding effects, our analysis controls for several firm-level characteristics known to be correlated with technological upgrading [34]. The PICS datasets collect a series of questions that address each firm's efforts for technological learning. This set of variables includes whether (a) the firm has employed staff exclusively for design/performing innovation/R\&D (Internal RED); and (b) has conducted on-the-job training $(O J T)$ in the past two years. To capture the impact of inter-organizational links on technological upgrading, we include dummy variables indicating whether the firm has subcontracted R\&D projects to other firms or organizations (External RED), exports any part of its output in the past year (Export), and is a member of a business association or chamber of commerce (Associational). The PICS also asked respondents to specify the percentage of college-graduated employees (\%College), the percentage of annual profits reinvested last year (\%Reinvestment), and whether their firms have received any ISO (International Organization for Standardization) certification (ISO), all of which is believed to represent each firm's technological capabilities. Finally, we control for the year of survey (Year; $0=2004$ or $1=2007$ ), firm age (Age; calculated by subtracting the year of firm establishment from the year of survey), and the natural logarithm of the number of full-time employees (Size).

\subsection{Statistical Methods}

Instead of simply analyzing the effect of being an MNC supplier, this study focuses on how different modes of value chain governance affect the paths of technological upgrading on the part of local suppliers. 
To this aim, we employ a latent class analysis (LCA) technique to empirically recognize different modes of relationships wherein supplier firms interact with their global buyers. These analyses are conducted using the maximum likelihood estimator that is available in the Mplus software, Version 7.2. Simply put, the purpose of LCA technique is to determine the unobserved "latent" cluster membership, which can be statistically inferred from the observed "manifest" response patterns. In the case that we have four manifest indicators $(A, B, C$, and $D)$, a classical LCA model can be expressed as:

$$
\pi_{i j k l t}=\pi_{t}^{X} \pi_{i t}^{A \mid X} \pi_{j t}^{B \mid X} \pi_{k t}^{C \mid X} \pi_{l t}^{D \mid X}
$$

where $\pi_{t}^{X}$ represents the odds of being clustered into latent class $t=1,2, \ldots, T$ of latent indicator $X$; $\pi_{i t}^{A \mid X}$ represents conditional probability of observing the $i$ th response to indicator $A ; \pi_{j t}^{B \mid X}, \pi_{k t}^{C \mid X}, \pi_{l t}^{D \mid X}$ represents the corresponding probabilities for indicators $B, C, D$, respectively [35]. Typically, a process of obtaining the best-fitting solution begins by assessing the baseline model with a single cluster solution, which serves as a null model $\left(H_{0}\right)$. Then, the LCA estimation is reiterated by increasing the number of latent classes incrementally until the best-fitting cluster solution is obtained.

From an analytical perspective, LCA has several key advantages. First, unlike traditional cluster analysis, LCA is a model-based empirical approach that estimates individual firms' probabilities of being involved in each latent class on the basis of observed response patterns [36]. Second, while standard cluster analysis relies upon the assumption that clustering variables are normally distributed, LCA is not based on the normality assumption and thus permits ordinal or nominal variables to be analyzed. Finally, LCA provides a set of goodness-of-fit indices, which helps us to decide on the optimal numbers of latent classes that fit the data best [37]. The most common approach is to utilize the Bayesian Information Criterion (BIC), which can be defined as:

$$
B I C_{L L}=-2 L L+\ln (N) M
$$

where $L L$ denotes the log-likelihood; $M$ denotes the number of parameters; $N$ denotes the sample size [35]. An empirical model with a lower score of BIC is considered to provide a better fit to the data, and is thus preferred over a model with a higher score of BIC. This measure is useful in comparing models with varying numbers of latent clusters. Compared to the chi-squared statistic that cannot be computed in cases involving sparse data, the BIC statistic provides a more flexible and probabilistic alternative.

Having identified the existing modes of value chain governance in the manufacturing sector in Thailand, we go further to analyze which of the modes of buyer-supplier relationships are associated with which aspects of technological upgrading of local suppliers. Since the outcome variables are binary, we need to model the conditional probabilities of achieving technological change $\operatorname{Pr}(Y=1 \mid X=x)$ as a function of explanatory variables. As is well known, logistic regression methods are the most suitable for this case. Thus, we use a logit regression approach where the dependent variable is assigned a value of 1 if a firm has achieved each type of technological upgrading in the last two years. Yet as our firm-level data is categorized by both region and industry, it is very likely that the independence assumption of observations is violated within region as well as within industry. The failure to adequately correct for within-cluster autocorrelation may bias standard errors downward, or even produce biased coefficients. To address this statistical issue, we cluster standard errors in all model specifications on both industry (12 categories) and region (7 categories) [38].

\section{Empirical Results}

\subsection{Results of Latent Class Analysis}

Table 1 shows the results of LCA with different numbers of clusters. In conducting this phase of the analysis, we limited our sample to MNC supplier firms with a question "Is your firm a supplier to a multi-national corporation?" Four PICS measures representing the nature of dyadic relationships between supplier firms and global buyers (MNC RED, Send, Specification, Standards) were entered as clustering variables. Determining the optimal number of latent clusters, we compared LCA results 
with varying numbers of clusters. The BIC statistic shows that a model with five latent clusters yields the lowest BIC and thus could be interpreted as the best fitting solution [37].

Table 1. The results of latent class analysis with a varying number of clusters.

\begin{tabular}{ccccccc}
\hline \multirow{2}{*}{ Criteria } & \multicolumn{7}{c}{ Number of Latent Clusters } \\
\cline { 2 - 7 } & $\mathbf{1}$ & $\mathbf{2}$ & $\mathbf{3}$ & $\mathbf{4}$ & $\mathbf{5}$ & $\mathbf{6}$ \\
\hline AIC & 13,040 & 12,474 & 12,366 & 12,163 & 12,077 & 12,083 \\
BIC & 13,064 & 12,523 & 12,439 & 12,261 & 12,198 & 12,229 \\
\hline
\end{tabular}

Notes: 2004 and 2007 Thailand PICS data. $n=1053$ MNC suppliers. AIC refers to Akaike Information Criterion. $\mathrm{BIC}$ refers to Bayesian Information Criterion.

Table 2 shows descriptive statistics for each of the latent clusters. The first cluster incorporates 235 local suppliers that are heavily engaged in R\&D cooperation with MNCs, but do not follow product specifications provided by their customer. This condition allows suppliers to exercise a high level of autonomy in production-related decisions insofar as the outcomes meet the standards that buyers require. We labelled this cluster as the 'cooperative network' in that this mode of value chain governance may foster intensive knowledge exchanges without limiting participating firms' technological initiatives. In contrast, the second cluster consists of suppliers that do not benefit from knowledge transfer and are controlled by tight specifications for the customers. This type of value chain governance does not leave room for knowledge transfer to occur, and is thus labeled as the 'buyer-driven manufacturing'. The third cluster depicts a situation where participating MNCs neither transfer technological knowledge to, nor enforce quality control mechanisms on local manufacturers. This mode of value chain governance is labeled as the 'market transaction'. The fourth cluster consists of MNC suppliers that are deeply embedded in knowledge transfer processes, but are also heavily dependent on the product designs supplied by customers for the bulk of their sales. In this governance mode, the process of OEM production appears to be strictly controlled by MNCs, given the fact that a majority of global retailer firms sends their own technicians to the production facilities owned by local supplier firms. We call this cluster the 'quasi-hierarchical manufacturing'. Finally, the firms belonging to the final cluster seem to get involved in knowledge transfer with a moderate level of autonomy in production-related decisions and go through a period of transition. This cluster is labeled as the 'transition period'.

Table 2. Descriptive statistics for each category of network modes.

\begin{tabular}{ccccccc}
\hline \multirow{2}{*}{ Variables } & \multirow{2}{*}{ Non-Supplier } & \multicolumn{5}{c}{ Network Modes } \\
\cline { 3 - 6 } & & Cooperative & Buyer-Driven & Market & Quasi-Hierarchical & Transition \\
\hline MNC R\&D & 0.00 & 1.00 & 0.00 & 0.00 & 0.94 & 0.47 \\
Send & 0.00 & 0.54 & 0.81 & 0.14 & 0.59 & 0.32 \\
Standards & 0.00 & 0.91 & 0.81 & 0.72 & 0.97 & 0.90 \\
Specification & 0.00 & 0.09 & 0.94 & 0.07 & 0.94 & 0.44 \\
Process & 0.35 & 0.70 & 0.51 & 0.59 & 0.58 & 0.55 \\
Minor Product & 0.62 & 0.91 & 0.81 & 0.81 & 0.85 & 0.84 \\
Major Product & 0.37 & 0.67 & 0.47 & 0.55 & 0.53 & 0.59 \\
Brand & 0.43 & 0.63 & 0.42 & 0.63 & 0.39 & 0.57 \\
Internal R\&D (\%) & 0.04 & 0.06 & 0.05 & 0.05 & 0.08 & 0.06 \\
OJT & 0.47 & 0.77 & 0.69 & 0.71 & 0.80 & 0.74 \\
External R\&D & 0.04 & 0.15 & 0.06 & 0.12 & 0.12 & 0.07 \\
Export & 0.30 & 0.77 & 0.84 & 0.75 & 0.69 & 0.77 \\
Associational & 0.40 & 0.66 & 0.65 & 0.65 & 0.63 & 0.67 \\
\% College & 17.78 & 23.68 & 19.62 & 23.26 & 21.95 & 22.51 \\
\% Reinvestment & 25.85 & 24.56 & 33.50 & 30.68 & 34.06 & 27.22 \\
ISO & 0.17 & 0.48 & 0.40 & 0.44 & 0.48 & 0.51 \\
Year & 0.47 & 0.51 & 0.26 & 0.29 & 0.48 & 0.39 \\
Age & 15.07 & 16.37 & 15.88 & 16.71 & 15.84 & 17.71 \\
Size & 101.16 & 279.52 & 129.31 & 141.11 & 182.69 & 181.37 \\
\hline
\end{tabular}

Notes: 2004 and 2007 Thailand PICS data. $n=2074$ firms. 
Figure 1 plots the distribution of each of the clusters by industry. This comparison clearly demonstrates the existence of within- as well as between-industry variation in buyer-supplier relationships. Although the probabilities of being in each category of network modes substantially differs across industries, Figure 1 shows that a large portion of variation still exists among firms within each industry.

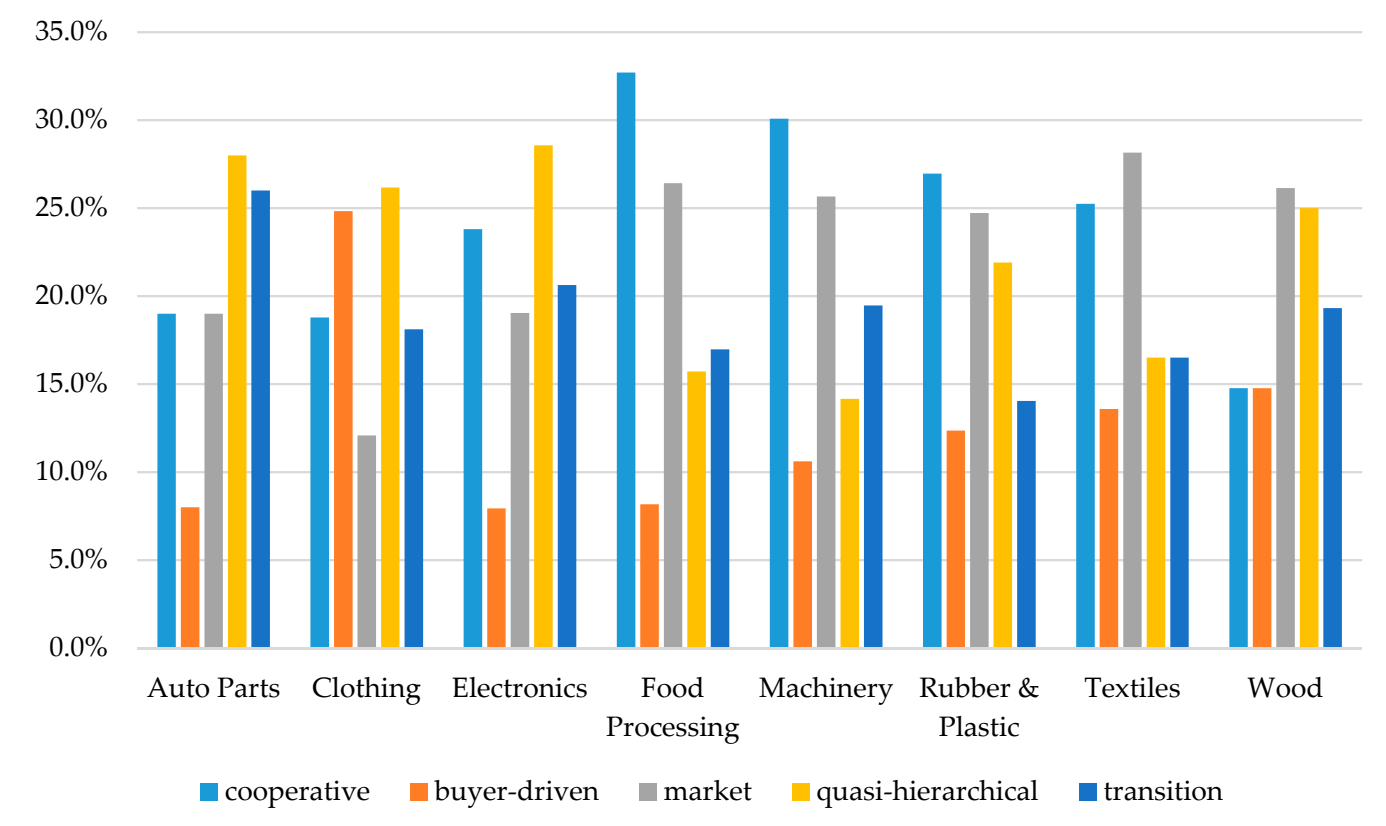

Figure 1. Distribution of latent clusters by industry. 2004 and 2007 Thailand PICS data; $n=1053$ MNC suppliers.

\subsection{Results of Logistic Regressions}

Under what conditions does integration into GPNs contribute to local supplier upgrading? To answer the primary question of this paper, we estimated two different model specifications for each of the technological upgrading variables. The first set of logit regressions reported in Table 3 includes a dummy variable for MNC suppliers without taking into account the different modes of value chain governance. Results show that being an MNC supplier is significantly and positively related to each type of technological upgrading outcomes except for the case of brand upgrading. Controlling for compositional differences in technological profiles, MNC suppliers are more likely to upgrade both product design and production processes compared with their non-supplier counterparts. By contrast, there is no indication in the results that being an MNC supplier is related to the development of a firm's brands.

In the second set of logit regressions in Table 3, we replicated the prior model specifications but included a set of dummy variables for different network modes in place of the MNC supplier dummy. Our findings reiterate the importance of being inserted into GPNs in fostering efficiency-enhancing types of technological upgrading (i.e., process and minor product upgrading), although the effect size varies considerably across network modes. With regards to minor product and process upgrading, MNC suppliers assigned for each of the clusters generally report better innovative outcomes than firms that do not interact with MNCs. On the contrary, the process of acquiring higher value activities, which generally involves the development of new product lines or brands, appears to be achieved mostly in the network modes that allow a high degree of autonomy. The involvement in either buyer-driven or quasi-hierarchical manufacturing is not associated with major product upgrading. More interestingly, being inserted into these two types of value chain governance is significantly associated with a lower tendency of brand upgrading. However, the involvement in value chain 
governance that allows suppliers greater autonomy in production-related decisions-i.e., collaborative networks or market transaction - is found to be significant in explaining both major product upgrading and brand upgrading.

Table 3. Results of logit regressions predicting each category of technological upgrading.

\begin{tabular}{|c|c|c|c|c|c|c|c|c|}
\hline \multirow{2}{*}{ Variables } & \multicolumn{4}{|c|}{ Model 1} & \multicolumn{4}{|c|}{ Model 2} \\
\hline & Process & $\begin{array}{l}\text { Minor } \\
\text { Product }\end{array}$ & $\begin{array}{c}\text { Major } \\
\text { Product }\end{array}$ & Brand & Process & $\begin{array}{l}\text { Minor } \\
\text { Product }\end{array}$ & $\begin{array}{l}\text { Major } \\
\text { Product }\end{array}$ & Brand \\
\hline MNC supplier & $\begin{array}{c}0.171^{* *} \\
(0.023)\end{array}$ & $\begin{array}{c}0.200 \text { ** } \\
(0.025)\end{array}$ & $\begin{array}{c}0.120 * * \\
(0.027)\end{array}$ & $\begin{array}{c}0.010 \\
(0.032)\end{array}$ & & & & \\
\hline GOV1-collaborative & & & & & $\begin{array}{c}0.267^{* *} \\
(0.139)\end{array}$ & $\begin{array}{c}0.239 * * \\
(0.028)\end{array}$ & $\begin{array}{l}0.211^{* *} \\
(0.037)\end{array}$ & $\begin{array}{c}0.100 \text { ** } \\
(0.032)\end{array}$ \\
\hline GOV2-buyer-driven & & & & & $\begin{array}{l}0.112 * \\
(0.054)\end{array}$ & $\begin{array}{c}0.199 * * \\
(0.036)\end{array}$ & $\begin{array}{c}0.042 \\
(0.066)\end{array}$ & $\begin{array}{c}-0.107 \text { * } \\
(0.043)\end{array}$ \\
\hline GOV3-market & & & & & $\begin{array}{c}0.171 * * \\
(0.022)\end{array}$ & $\begin{array}{c}0.182 \text { ** } \\
(0.025)\end{array}$ & $\begin{array}{l}0.109 * \\
(0.044)\end{array}$ & $\begin{array}{c}0.091 \text { ** } \\
(0.032)\end{array}$ \\
\hline GOV4—quasi-hierarchical & & & & & $\begin{array}{c}0.145^{* *} \\
(0.044)\end{array}$ & $\begin{array}{c}0.187^{* *} \\
(0.034)\end{array}$ & $\begin{array}{c}0.066 \\
(0.038)\end{array}$ & $\begin{array}{c}-0.128 \text { * } \\
(0.050)\end{array}$ \\
\hline GOV5-transition & & & & & $\begin{array}{l}0.117 * \\
(0.050)\end{array}$ & $\begin{array}{c}0.190 * * \\
(0.022)\end{array}$ & $\begin{array}{l}0.140 \text { ** } \\
(0.041)\end{array}$ & $\begin{array}{c}0.047 \\
(0.034)\end{array}$ \\
\hline Internal R\&D (\%) & $\begin{array}{c}4.944 \text { ** } \\
(1.354)\end{array}$ & $\begin{array}{c}2.542 \\
(2.143)\end{array}$ & $\begin{array}{l}6.640 * * \\
(2.320)\end{array}$ & $\begin{array}{c}3.200 \\
(2.014)\end{array}$ & $\begin{array}{c}4.990 * * \\
(1.548)\end{array}$ & $\begin{array}{c}2.570 \\
(2.122)\end{array}$ & $\begin{array}{l}6.763 * * \\
(2.267)\end{array}$ & $\begin{array}{c}3.533 \\
(1.944)\end{array}$ \\
\hline OJT & $\begin{array}{c}0.105^{* *} \\
(0.014)\end{array}$ & $\begin{array}{c}0.080 * * \\
(0.009)\end{array}$ & $\begin{array}{c}0.092 * * \\
(0.019)\end{array}$ & $\begin{array}{c}0.019 \\
(0.036)\end{array}$ & $\begin{array}{c}0.104 * * \\
(0.015)\end{array}$ & $\begin{array}{c}0.080 * * \\
(0.001)\end{array}$ & $\begin{array}{c}0.093 * * \\
(0.020)\end{array}$ & $\begin{array}{c}0.024 \\
(0.037)\end{array}$ \\
\hline External R\&D & $\begin{array}{c}0.103 \\
(0.065)\end{array}$ & $\begin{array}{c}0.112 * * \\
(0.010)\end{array}$ & $\begin{array}{c}0.158 * * \\
(0.025)\end{array}$ & $\begin{array}{c}0.132 * * \\
(0.024)\end{array}$ & $\begin{array}{c}0.092 \\
(0.063)\end{array}$ & $\begin{array}{c}0.109 * * \\
(0.014)\end{array}$ & $\begin{array}{c}0.151 \text { ** } \\
(0.019)\end{array}$ & $\begin{array}{c}0.125^{* *} \\
(0.022)\end{array}$ \\
\hline Export & $\begin{array}{c}-0.041 \\
(0.028)\end{array}$ & $\begin{array}{c}-0.058 * \\
(0.024)\end{array}$ & $\begin{array}{c}0.002 \\
(0.010)\end{array}$ & $\begin{array}{c}0.110 \\
(0.067)\end{array}$ & $\begin{array}{c}-0.041 \\
(0.028)\end{array}$ & $\begin{array}{c}-0.059 * \\
(0.024)\end{array}$ & $\begin{array}{c}0.001 \\
(0.010)\end{array}$ & $\begin{array}{c}0.108 \\
(0.061)\end{array}$ \\
\hline Associational & $\begin{array}{c}0.009 \\
(0.033)\end{array}$ & $\begin{array}{l}0.065 * \\
(0.019)\end{array}$ & $\begin{array}{c}0.052 * * \\
(0.003)\end{array}$ & $\begin{array}{c}-0.004 \\
(0.023)\end{array}$ & $\begin{array}{c}0.009 \\
(0.033)\end{array}$ & $\begin{array}{c}0.065^{* *} \\
(0.019)\end{array}$ & $\begin{array}{c}0.052 \text { ** } \\
(0.002)\end{array}$ & $\begin{array}{l}-0.006 \\
(0.023)\end{array}$ \\
\hline$\%$ College & $\begin{array}{c}0.001 \\
(0.001)\end{array}$ & $\begin{array}{c}0.000 \\
(0.000)\end{array}$ & $\begin{array}{c}0.001 \\
(0.001)\end{array}$ & $\begin{array}{c}0.003 * * \\
(0.001)\end{array}$ & $\begin{array}{c}0.001 \\
(0.001)\end{array}$ & $\begin{array}{c}0.001 \\
(0.001)\end{array}$ & $\begin{array}{c}0.001 \\
(0.001)\end{array}$ & $\begin{array}{c}0.003 * * \\
(0.001)\end{array}$ \\
\hline$\%$ Reinvestment & $\begin{array}{c}0.000 \\
(0.000)\end{array}$ & $\begin{array}{c}0.000 \\
(0.000)\end{array}$ & $\begin{array}{c}0.000 \\
(0.000)\end{array}$ & $\begin{array}{c}-0.000 \\
(0.000)\end{array}$ & $\begin{array}{c}0.000 \\
(0.000)\end{array}$ & $\begin{array}{c}0.000 \\
(0.000)\end{array}$ & $\begin{array}{c}0.000 \\
(0.000)\end{array}$ & $\begin{array}{l}-0.000 \\
(0.000)\end{array}$ \\
\hline ISO & $\begin{array}{c}0.161 * * \\
(0.021)\end{array}$ & $\begin{array}{c}0.064 * * \\
(0.015)\end{array}$ & $\begin{array}{c}0.090 * * \\
(0.019)\end{array}$ & $\begin{array}{c}0.044 \\
(0.025)\end{array}$ & $\begin{array}{c}0.162 \text { ** } \\
(0.023)\end{array}$ & $\begin{array}{c}0.064 * * \\
(0.016)\end{array}$ & $\begin{array}{c}0.089 * * \\
(0.018)\end{array}$ & $\begin{array}{c}0.043 \\
(0.023)\end{array}$ \\
\hline Year & $\begin{array}{c}-0.039 * \\
(0.018)\end{array}$ & $\begin{array}{c}0.133 * * \\
(0.015)\end{array}$ & $\begin{array}{c}0.023 \\
(0.044)\end{array}$ & $\begin{array}{l}-0.063 \\
(0.039)\end{array}$ & $\begin{array}{c}-0.044 * \\
(0.018)\end{array}$ & $\begin{array}{c}0.131^{* *} \\
(0.015)\end{array}$ & $\begin{array}{c}0.018 \\
(0.043)\end{array}$ & $\begin{array}{c}-0.061 \\
(0.040)\end{array}$ \\
\hline Age & $\begin{array}{c}-0.000 \\
(0.001)\end{array}$ & $\begin{array}{l}-0.001 \\
(0.001)\end{array}$ & $\begin{array}{c}-0.004^{* *} \\
(0.001)\end{array}$ & $\begin{array}{c}0.004 \\
(0.001)\end{array}$ & $\begin{array}{l}-0.000 \\
(0.001)\end{array}$ & $\begin{array}{l}-0.001 \\
(0.001)\end{array}$ & $\begin{array}{c}-0.004 \text { ** } \\
(0.001)\end{array}$ & $\begin{array}{c}0.004 \\
(0.001)\end{array}$ \\
\hline Size & $\begin{array}{l}0.000 * * \\
(0.000)\end{array}$ & $\begin{array}{l}-0.000 \\
(0.000)\end{array}$ & $\begin{array}{c}0.000 \\
(0.000)\end{array}$ & $\begin{array}{c}0.000 \\
(0.000)\end{array}$ & $\begin{array}{c}0.000 * * \\
(0.000)\end{array}$ & $\begin{array}{l}-0.000 \\
(0.000)\end{array}$ & $\begin{array}{c}0.000 \\
(0.000)\end{array}$ & $\begin{array}{c}0.000 \\
(0.000)\end{array}$ \\
\hline
\end{tabular}

Notes: 2004 and 2007 Thailand PICS data. $n=2074$ firms. ${ }^{*} p<0.05,{ }^{* *} p<0.01$. Robust standard errors in parenthesis are clustered on industry and region.

Aside from the key explanatory variables, we found that internal $R \& D$ is a statistically significant predictor of both process and major product upgrading, whilst its effects on minor product or brand upgrading are not significant. Results also suggest that the effects of OJT are consistently associated with a significantly increased tendency of product and process upgrading. Regarding the effects of localized networks in which firms are embedded, we found external R\&D activities to be positively related to product and brand upgrading, while associational activities are significantly related to both types of product upgrading. Finally, it was found that the effects of local firms' technological competencies are less consistent. Although having ISO certification is significantly and positively related to product and process upgrading, the percentage of college-educated employees only has a significant correlation with brand upgrading. We also found that the fraction of annual profits reinvested, which is assumed to represent firms' investment capabilities, is not significantly associated with any types of technological upgrading. 


\section{Discussion and Conclusions}

A question fundamental to the sustainability of global chain governance is whether local manufacturers operating in value chains can realize the potential to move into higher value activities. The answer to this question is not straightforward and, as illustrated in this article, requires a sophisticated understanding of the inherent relationality in buyer-supplier networks. Although the impacts of insertion into GPNs on local supplier upgrading have been acknowledged, studies have yet to fully incorporate the configurations of heterogeneous buyer-supplier relationships within GPNs into empirical testing. To address this gap, this study provides a more nuanced view that understands international knowledge transfer fundamentally as a relational process in which power relations between MNCs and local manufacturers are intertwined with different stages of technological change. The major findings obtained from our analyses are discussed as follows.

First, local manufacturers in Thailand are incorporated into GPNs in different ways. Our results suggest that the way GPNs are governed is neither purely hierarchical nor cooperative but has considerable variation that is not fully attributable to the industrial composition of firms. In a departure from previous studies that have relied upon an arbitrary grouping of buyer-supplier relationships [39], we used a recent technique of LCA to identify five latent clusters of local suppliers with qualitatively distinct patterns of relationships with their global buyers. In this way, our investigation broadens the empirical base for understanding the conditions in which developing country manufacturers operate in this era of globalization. Based on these findings, we argue that the effects of being inserted into GPNs should be discussed in relation to the features of network structures in which local firms are embedded.

Second, the effects of insertion into GPNs do not operate in the same way in different types of technological upgrading. Most notably, we found that the opportunities for acquiring higher value activities appear to be suppressed in the settings where MNCs exerts a high level of control over the process of production and strictly specify product design and process parameters. However, it is also found that efficiency-enhancing types of technological upgrading-i.e., process and minor product upgrading - appear to be fostered by being inserted in GPNs irrespective of the types of buyer-supplier relationships. On one hand, these findings are consistent with Humphrey and Schmitz's [7] observation of Brazilian manufacturers working for MNCs, which conclude that 'insertion in a quasi-hierarchical chain offers very favorable conditions for fast process and product upgrading but hinders functional upgrading'. On the other hand, our findings run counter on Gereffi [40] who argues that participation in global value chains generally leads to 'organizational succession' through which participating suppliers move from simple assembly roles of imported parts to more sophisticated roles of ODM and OBM production.

Obviously, our conclusions cannot be automatically generalized to other countries without taking into account cross-national differences in the institutional contexts that may influence the manner by which value chain governance impacts technological upgrading. For decades, Japanese MNCs-e.g., Toyota and Honda-have had enormous effects on the development of manufacturing sectors in Thailand. Cross-cultural studies of organizational culture have often described Japanese MNCs as being embedded within tightly integrated intra-firm systems [41]. Studies also suggest that Japanese MNCs' national inward orientation contributes to maintaining a high level of organizational coherence, but may also discourage firms from developing reciprocal relationships with diverse local institutions and effectively tapping into the local knowledge base [42]. Given these organizational contexts, it can be plausibly argued that Japan's ethnocentric centralized R\&D mode has played a significant role in patterning the structural characteristics of buyer-supplier relationships in Thailand. Of course, our investigation was not structured in a way that enables us to detect the effects of institutional contexts in which firms operate. For our research purposes here, it is sufficient to note that the findings should be interpreted in relation to Thailand's specific historical and institutional contexts.

Besides the contributions of this study, we recognize several limitations from which directions for future research emerge. First, the data we employed to test the hypothesized relationships were 
collected between 2004 and 2007, which correspond to the pre-financial crisis period. Efforts to replicate our findings based on more recent data sets may provide stronger policy implications. Second, although the impacts of different modes of organizing global value chains on local supplier upgrading have been examined in the current study, our investigation does not tell us about the determinants of value chain governance. In particular, the management literature suggests that it is the focal firms' perception of the risk of supplier performance failure that impacts the ways that the value chain is governed [22,23]. In this sense, an investigation that is designed from the perspective of global focal firms may help us to complete the picture of the dynamics of global chain governance. The results presented here have broader policy implications for industrial upgrading in the context of developing countries. Over the last few decades, latecomer economies in the Southeast Asian region have strived to integrate their manufacturing sectors into GPNs in the hope that it will stimulate international knowledge flows. However, our findings suggest that integration into GPNs is not the same as local technological upgrading. At the early stage of industrial upgrading, insertion into GPNs could be an effective strategy to promote fast technological catching-up in the sphere of production. But as suppliers acquire the abilities to handle the entire working process, asymmetry in power and control between global and local actors may operate as a barrier to the development of local competitiveness in the sphere of design, marketing, and branding, which are typically considered the core competencies of global lead firms. Related to this argument, recent studies observed that knowledge transfers flowing from interaction with MNCs tend to be confined to the sphere of production, mostly localizing efforts of innovation outcomes produced in first-world economies [43]. Thus, to ensure the sustainability of industrial strategies through participation in GPNs, developing countries should focus on how to avoid being locked into quasi-hierarchical value chain governance and translate 'organizational succession' into reality.

Author Contributions: Sungchul Cho designed the research and drafted the manuscript. Up Lim guided this work and provided extensive revisions during the study. Both authors wrote, read, and approved the final manuscript.

Conflicts of Interest: The authors declare no conflict of interest.

\section{References}

1. UNIDO. Industrial Development Report 2002/2003. Competing Through Innovation and Learning; United Nations: Vienna, Austria, 2002.

2. Crespo, J.; Suire, R.; Vicente, J. Lock-in or lock-out? How structural properties of knowledge networks affect regional resilience. J. Econ. Geogr. 2014, 14, 199-219.

3. Grabher, G. The Embedded Firm; Routledge: London, UK, 1993.

4. Dicken, P. Global Shift: Mapping the Changing Contours of the World Economy; Sage: London, UK, 2011.

5. Yeung, H.W.C. Rethinking relational economic geography. Trans. Inst. Br. Geogr. 2005, 30, 37-51. [CrossRef]

6. Hobday, M. The electronics industries of the Asia-Pacific: Exploiting international production networks for economic development. Asia Pac. Econ. Lit. 2001, 15, 13-29. [CrossRef]

7. Humphrey, J.; Schmitz, H. How does insertion in global value chains affect upgrading in industrial clusters? Reg. Stud. 2002, 36, 1017-1027. [CrossRef]

8. Kim, L.; Nelson, R.R. Technology, Learning, and Innovation: Experiences of Newly Industrializing Economies; Cambridge University Press: Cambridge, UK, 2000.

9. Lee, K.; Lim, C. Technological regimes, catching-up and leapfrogging: Findings from the Korean industries. Res. Policy 2001, 30, 459-483. [CrossRef]

10. Amsden, A.H. Asia's Next Giant: South Korea and Late Industrialization; Oxford University Press: New York, NY, USA, 1989.

11. Lall, S. Learning to Industrialize: The Acquisition of Technological Capability by India; Macmillan Press: London, UK, 1987.

12. Schmitz, H. Global competition and local co-operation: Success and failure in the Sinos Valley, Brazil. World Dev. 1999, 27, 627-650. [CrossRef] 
13. Fagerberg, J.; Srholec, M.; Verspagen, B. Innovation and economic development. In Handbook of the Economics of Innovation; Hall, B.H., Rosenberg, N., Eds.; North Holland: Amsterdam, The Netherlands, 2010; pp. 833-872.

14. Hall, B. Innovation and diffusion. In The Oxford Handbook of Innovation; Fagerberg, J., Mowery, D.C., Nelson, R., Eds.; Oxford University Press: Oxford, UK, 2007; pp. 459-484.

15. Kim, L. Imitation to Innovation: The Dynamics of Korea's Technological Learning; Harvard Business School Press: Cambridge, MA, USA, 1997.

16. Amin, A.; Thrift, N.J. Globalization, Institutions, and Regional Development in Europe; Oxford University Press: New York, NY, USA, 1994.

17. Hess, M.; Yeung, H.W. Whither global production networks in economic geography? Past, present, and future. Environ. Plan. A 2006, 38, 1193-1204.

18. Zanfei, A. Transnational firms and the changing organisation of innovative activities. Camb. J. Econ. 2000, 24, 515-542. [CrossRef]

19. Chong, Y.Q.; Wang, B.; Tan, G.L.Y.; Cheong, S.A. Diversified firms on dynamical supply chain cope with financial crisis better. Int. J. Prod. Econ. 2014, 150, 239-245. [CrossRef]

20. Mizgier, K.J.; Wagner, S.M.; Holyst, J.A. Modeling defaults of companies in multi-stage supply chain networks. Int. J. Prod. Econ. 2012, 135, 14-23. [CrossRef]

21. Lee, B.K.; Zhou, R.; de Souza, R.; Park, J. Data-driven risk measurement of firm-to-firm relationships in a supply chain. Int. J. Prod. Econ. 2016, 180, 148-157. [CrossRef]

22. Mizgier, K.J.; Wagner, S.M.; Jüttner, M.P. Disentangling diversification in supply chain networks. Int. J. Prod. Econ. 2015, 162, 115-124. [CrossRef]

23. Dolan, C.; Humphrey, J. Changing governance patterns in the trade in fresh vegetables between Africa and the United Kingdom. Environ. Plan. A 2004, 36, 491-509. [CrossRef]

24. Ivarsson, I.; Alvstam, C.G. Supplier Upgrading in the Home-furnishing Value Chain: An Empirical Study of IKEA's Sourcing in China and South East Asia. World Dev. 2010, 38, 1575-1587. [CrossRef]

25. Ernst, D.; Kim, L. Global production networks, knowledge diffusion, and local capability formation. Res. Policy 2002, 31, 1417-1429. [CrossRef]

26. Vang, J.; Asheim, B. Regions, absorptive capacity and strategic coupling with high-tech TNCs: Lessons from India and China. Sci. Technol. Soc. 2006, 11, 39-66. [CrossRef]

27. Coe, N.M.; Hess, M.; Yeung, H.W.; Dicken, P.; Henderson, J. ‘Globalizing' regional development: A global production networks perspective. Trans. Inst. Br. Geogr. 2004, 29, 468-484. [CrossRef]

28. UNCTAD. World Investment Report 2014. Investing in the SDGs: An Action Plan; United Nations: Geneva, Switzerland, 2014.

29. UNCTAD. World Investment Report 2005. Transnational Corporations and the Internationalization of RED; United Nations: New York, NY, USA, 2005.

30. Lall, S.; Narula, R. FDI and Its Role in Economic Development: Do We Need a New Agenda?; Research Memoranda No. 019; MERIT, Maastricht Economic Research Institute on Innovation and Technology: Maastricht, The Netherlands, 2004.

31. Chaminade, C.; Vang, J. Innovation policy for small and medium size SMEs in Asia: An innovation systems perspective. In Handbook of Research on Asian Business; Yeung, H.W., Ed.; Edward Elgar: Cheltenham, UK, 2006; pp. 381-408.

32. OECD. Oslo Manual: The Measurement of Scientific and Technological Activities: Proposed Guidelines for Collecting and Interpreting Technological Innovation Data; OECD, Organisation for Economic Co-Operation and Development: Paris, France, 1992.

33. Hobday, M. East Asian latecomer firms. World Dev. 1995, 23, 1171-1193. [CrossRef]

34. Hedge, D.; Shapira, P. Knowledge, technology trajectories, and innovation in a developing country context: Evidence from a survey of Malaysian firms. Int. J. Technol. Manag. 2007, 40, 349-370.

35. Vermunt, J.K.; Magidson, J. Latent class cluster analysis. In Applied Latent Class Analysis; Hagenaars, J.A., McCutcheon, A.L., Eds.; Cambridge University Press: London, UK, 2002; pp. 89-106.

36. Clogg, C.C. Latent class models for measuring. In Latent Trait and Latent Class Models; Langeheine, R., Rost, J., Eds.; Plenum Press: New York, NY, USA, 1988; pp. 173-205.

37. Muthén, B.; Muthén, L. Integrating person-centered and variable-centered analyses: Growth mixture modeling with latent trajectory classes. Alcohol. Clin. Exp. Res. 2000, 24, 882-891. [CrossRef] [PubMed] 
38. Rogers, W. Regression standard errors in clustered samples. Stata Tech. Bull. 1993, 13, 19-23.

39. Saliola, F.; Zanfei, A. Multinational firms, global value chains and the organization of knowledge transfer. Res. Policy 2009, 38, 369-381. [CrossRef]

40. Gereffi, G. International trade and industrial upgrading in the apparel commodity chain. J. Int. Econ. 1999, 48, 37-70. [CrossRef]

41. Cantwell, J.; Zhang, Y. Why is R\&D internationalization in Japanese firms so low? A path-dependent explanation. Asian Bus. Manag. 2006, 5, 249-269.

42. Lam, A. Organizational learning in multinationals: R\&D networks of Japanese and US MNEs in the UK. J. Manag. Stud. 2003, 40, 673-703.

43. Frank, A.G.; Cortimiglia, M.N.; Ribero, J.L.D.; de Oliveira, L.S. The effect of innovation activities on innovation outputs in the Brazilian industry: Market-orientation vs. technology-acquisition strategies. Res. Policy 2016, 45, 577-592. [CrossRef]

(C) 2016 by the authors; licensee MDPI, Basel, Switzerland. This article is an open access article distributed under the terms and conditions of the Creative Commons Attribution (CC-BY) license (http://creativecommons.org/licenses/by/4.0/). 